\title{
Formulation of fishburgers with the addition of different protein sources and taro flour
}

\author{
Christiane Neves Maciel $^{1}$ (i) Luiz Fernando Florêncio Seller ${ }^{1}$ (D) Agnaldo Borge de Souza $^{1}$ (D) \\ Poliana Fernandes de Almeida ${ }^{* *}$ (D)
}

${ }^{1}$ Instituto Federal de Educação, Ciência e Tecnologia de Mato Grosso, Campus São Vicente (IFMT), 78106970, Campo Verde, MT, Brasil. E-mail: poliana.almeida@svc.ifmt.edu.br. *Corresponding author.

ABSTRACT: The present study aims to develop Nile tilapia hamburger with incorporation of whey, collagen from chicken feet and taro flour. A complete factorial design $2^{3}$ was performed to investigate the influence of the variables on weight loss, shrinkage, color and shear force, that were used to propose mathematical models. Proximate composition, microbiological characteristics and sensory properties were also evaluated. Factors such as taro flour and whey were significant and contributed to a higher yield for fish burgers, with negative effects on shrinkage and weight loss. The fishburgers had a soft texture, although collagen and its interaction with taro flour contributed to the increase in shear force. The factors had influence only on the $b^{*}$ value with yellowish hue. The protein and ash values obtained were higher than those of the control formulation. The sensory characteristics of the hamburgers were not affected by the factors, being all classified with high acceptability. The formulation represented by the central point (F9) containing 3.0\% of taro flour, $0.5 \%$ chicken feet collagen and $3.0 \%$ powdered whey, obtained greater purchase intention. Therefore, the addition of taro flour, collagen from chicken feet and whey is an alternative in the use of industrial by-products to add value to fish burgers with market potential.

Key words: hamburgers, chicken feet collagen, whey, technological characteristics, sensory quality.

Formulação de fishburgers com adição de diferentes fontes proteicas e farinha de taro

RESUMO: O objetivo do presente estudo foi desenvolver hambúrguer de tilapia do Nilo com a incorporação de soro de leite, colágeno de pés de frango e farinha de taro. Para tanto, um planejamento fatorial $2^{3}$ completo foi realizado para investigar a influência das variáveis sobre a perda de peso, encolhimento, cor e força de cisalhamento e propor modelos matemáticos. Avaliaram-se também a composição centesimal, características microbiológicas e propriedades sensoriais. Os fatores como farinha de taro e whey foram significativos e contribuiram com o maior rendimento dos hambúrgueres com efeitos negativos sobre a perda de peso e encolhimento. Os hambúrgueres apresentaram uma textura macia, embora o colágeno e sua interação com a farinha de taro tenham colaborado com o aumento da força de cisalhamento. Os fatores influenciaram somente o valor de $b^{*}$ com tonalidade amarelada. Os valores de proteina obtidos foram maiores que da formulação controle. As características sensoriais dos hambúrgueres não foram afetadas pelos fatores, sendo todos classificados com alta aceitabilidade. A formulação representada pelo ponto central (F9) contendo 3,0\% de farinha de taro, 0,5\% de colágeno de pés de frango e 3,0\% de soro de leite em pó, obteve maior intenção de compra. Portanto, a adição de farinha de taro, colágeno de pés de frango e soro de leite é uma alternativa no uso de subprodutos industriais para agregar valor aos hambúrgueres de peixe com potencial mercadológico.

Palavras-chave: hambúrgueres, colágeno de pés de frango, soro de leite, características tecnológicas, qualidade sensorial.

\section{INTRODUCTION}

New meat products that are easy to prepare and have healthier appeal have been developed to satisfy consumers looking for convenience (TREVISAN et al., 2016), such as the development of products with less fat content and the addition of beneficial ingredients. However, according to RIOS et al. (2014), fat replacement is a challenging task, since it has a strong influence on the structure of food and sensory characteristics.
Hydrocolloids perform numerous functions in foods, such as: gelling, thickener, dispersant, bonding with water, stabilizer, film formation, foam formation among others (FUNAMI, 2011) and can be used in food formulations as fat replacement. Taro (Colocasiaesculenta L. Schott) or coco-yam has constituents that represent hydrocolloids, being a little explored product with interesting properties. Among the root crops, taro is perhaps most widely prepared or processed into more consumable forms in the world (ABERA et al., 2017). 
Taro is a starch-rich corm and can be used in several food products in order to improve their nutritional, functional and technological properties, containing about $9.00 \%$ to $12.22 \%$ moisture, $1.64 \%$ to $3.11 \%$ ash and $14.73 \%$ to $16.28 \%$ protein (ARICI et al., 2016). Some work was observed with the use of taro flour to improve the organoleptic qualities of food products such as breads (ARICI et al., 2016), edible ice creams, yogurts, snacks, cakes, pasta, among others (NJINTANG et al., 2016), however, research with the taro flour application in processed meat products has not been identified.

Gelatin is also considered an important hydrocolloid and according to OMAR et al. (2018), is one of the most common ingredients used in a wide range of food products. SARBON et al. (2013) points out that its application can promote increased elasticity, consistency and stability of foods without causing negative effects in flavor. The partial hydrolysis of collagen gives rise to gelatin, which is obtained mostly by mammalian resources. An alternative source for gelatin extraction are poultry by-products, such as chicken feet which, according to some authors, have a high amount of protein represented by collagen (ALMEIDA \& LANNES, 2013; SARBON et al., 2013; ALMEIDA \& LANNES, 2017; SANTANA et al., 2020).

Whey protein can be used in combination with hydrocolloids, it is a by-product of the cheese industry and is of high biological value in addition to having diversified functionality and relatively low cost, making it the ideal ingredient in the formulation of a wide variety of food products (KILARA \& VAGHELA, 2018).

Considering that fish meat is rich in nutrients, according to SILVA et al. (2016), there is a need for ways to increase fish consumption such as the development of innovative products, particularly fishburgers. Therefore, the objective of this research was to evaluate the influence of the incorporation of different protein sources such as: whey protein and collagen extracted from chicken feet as well as the addition of taro flour on the physical-chemical, technological and sensory characteristics of fishburger.

\section{MATERIALS AND METHODS}

The procedures were performed in the Biotechnology Laboratory of the Federal Institute of Mato Grosso (IFMT) Campus São Vicente (Cuiabá, MT, Brazil). Chicken feet were obtained from IFMT and Nile tilapia (Oreochromisniloticus) fillets were purchased from BomFuturo ${ }^{\circledR}$ Pisciculture Group (Campo Verde, MT, Brazil). Taro tubers, known as cocoyam (Colocasia esculenta) and other ingredients were purchased from the local market.

\section{Taro flour elaboration}

The taro flour was obtained by adapting the methodology described by DIAS (2020). Taro roots were washed, peeled, thinly sliced $(1,5 \mathrm{~mm})$ and bleached in water at $100{ }^{\circ} \mathrm{C}$ for 30 seconds. The taro slices were oven dried at $55{ }^{\circ} \mathrm{C}$ for $12 \mathrm{hr}$. The dried taro slices were taken to the milling process in a knife mill with mesh 20 sieve, model MA580 $\left(\right.$ Marconi $\left.^{\circledR}\right)$. The flour obtained was stored for 4 days in polyethylene bags, protected from light at $25^{\circ} \mathrm{C}$.

\section{Gelatin extraction}

Collagen from chicken feet was obtained by reproducing the procedure adopted by ALMEIDAand LANNES (2016), where the chicken feet were washed, cut, pre-treated with acetic acid $(4.0 \%$ for $16 \mathrm{hr})$ and heated in water $\left(55^{\circ} \mathrm{C}\right.$ for $\left.13 \mathrm{hr}\right)$ for complete extraction. The solution was filtered, oven dried $\left(50^{\circ} \mathrm{C}\right.$ for $13 \mathrm{hr}$ ), milled to obtain the powder, and stored in polyethylene bags at $25^{\circ} \mathrm{C}$ protected from light for thirty days.

\section{Fishburgers formulation}

For the production of the control formulation, Nile tilapia fillets $(78 \%)$ were ground in a grinder with a $5 \mathrm{~mm}$ disc and later homogenized with the ingredients: vegetable oil $(3.0 \%)$, textured soy protein $(4.0 \%) \quad\left(\mathrm{Jasmine}^{\circledR}\right)$, salt $(1.5 \%)$, dehydrated garlic $(0.5 \%)$, monosodium glutamate $(0.3 \%)$ (Ajinomoto $\left.{ }^{\circledR}\right)$, antioxidant sodium erythorbate $(0.05 \%)\left(\right.$ SBR foods $\left.{ }^{\circledR}\right)$ and water $(13 \%)$. The mixture was divided, molded into $100 \mathrm{~g}$ portions and wrapped in polyethylene plastics (properties: water vapor transmission rate of $3000 \mathrm{~mL} \mathrm{~m}^{-2}$ for $24 \mathrm{hr}$ and oxygen transmission rate of $120 \mathrm{~mL} \mathrm{~m}^{-2}$ for $24 \mathrm{hr}$ at $85 \%$ of relative humidity) (FELLOWS, 2006).

The beef burgers were frozen at $-18^{\circ} \mathrm{C}$ until the start of analysis. To investigate the influence of factors on the quality characteristics of hamburgers, a complete $2^{3}$ factorial planning with 03 repetitions at the central point was used. The factors were the: taro flour $(02 \%, 03 \%$ and $04 \%)$, chicken collagen $(0.2 \%$, $0.5 \%$ and $0.8 \%)$ and whey protein $(02 \%, 03 \%$ and $04 \%$ ). In the 11 experimental formulations, the oil and the textured soy protein were substituted by the combinations of the analyzed factors with addition of water to complete $100 \%$.

\section{Physicochemical composition}

The hamburgers were cooked on a grill at $200{ }^{\circ} \mathrm{C}$ until reaching $75^{\circ} \mathrm{C}$ in the product 
center, which was monitored using a portable digital skewer thermometer. Moisture, ash, fat and protein crude analyses were performed (AOAC, 2000). The experiments were performed in triplicate and expressed as $\mathrm{g} / 100 \mathrm{~g}$ of hamburger.

\section{Physical analyses}

The yield was calculated by relating the weight of the cooked burger to the weight of the raw burger and the shrinkage (\%) was based on the variation of the diameter of the raw and cooked product with the aid of a caliper (TREVISAN et al., 2016). The experimental color was determined by the CIELab system using the Hunter Lab equipment (England - UK). The average of three readings was obtained and the values expressed in $\mathrm{L}^{*}$ (luminosity, $100=$ white, $0=$ black), $a^{*}$ (green/red intensity) and $b^{*}$ (blue/yellow intensity).

The fishburgers texture is directly related to the shear force, thus the instrumental analysis of samples with $2.5 \mathrm{~cm}$ of diameter was performed by texturometer the TA.XT plus (Stable Micro Systems, UK) with a Warner Bratzler probe with $1.01 \mathrm{~mm}$ of thickness, $64.94 \mathrm{~mm}$ of height, $44.90 \mathrm{~mm}$ of width and a V-shaped cutting blade with a 60 degree angle, calibrated with a standard weight of $5 \mathrm{Kg}$. The test parameters were: pre-test speed of $5.00 \mathrm{~mm} / \mathrm{s}$, test speed of $10 \mathrm{~mm} / \mathrm{s}$, post-test speed $10 \mathrm{~mm} / \mathrm{s}$. The peak of the force necessary to cut the samples was expressed in Newton (N) (OLIVEIRA et al., 2016).

\section{Microbiological analysis}

Samples of the cooked hamburgers (Control, F1, F8 and F9) were subjected to microbiological analysis to ensure the food safety in the sensory analysis. For this purpose, analyzes of coliforms at $45{ }^{\circ} \mathrm{C}$, Staphylococcus coagulase positive/g and Salmonella sp/25 g were performed and evaluated in accordance with Brazilian law (BRAZIL, 2001).

\section{Sensory analysis}

The analysis of sensory acceptability of fishburgers representing the extremes of factorial planning and central point (Control, F1, F8 and F9), duly approved by the IFMT Research Ethics Committee (CAAE: 87608518.6.0000.8055), was performed with the participation of 80 untrained tasters aged 18 to 50 years.

The methodology of STONE \& SIDEL (1993) was used with the aid of a pre-established scale from 1 to 9 points ranging from ranging from 1 - dislike extremely to 9 - like extremely. A 5-point structured scale was used to verify the purchase intention varying from 1 - definitely would not buy it to 5 - definitely would buy it. The samples were kept in a polystyrene box at a temperature of 50 to $55^{\circ} \mathrm{C}$ and served randomly in $1.5 \mathrm{~cm}$ diameter cubes in disposable and properly coded dishes. Attributes such as: taste, aroma, texture, color and general aspect were evaluated.

\section{Statistical analysis}

The results obtained were analyzed statistically by means of analysis of variance (ANOVA) and Tukey's test at the 5\% level of significance using Statistica ${ }^{\circledR}$ software version 13.5. The response surface was used to represent the regression analysis of effects significant interactions. The effects, interactions and coefficients values were obtained and applied in the basic mathematical model used to adjust the data where $Y$ is the expected response, $\beta_{0}$ is the constant term, $\beta_{1,} \beta_{2}$, and $\beta_{12}$ are the regression terms:

$Y=\beta_{0}+\beta 1 x_{1}+\beta 2 x_{2}+\beta_{12} x_{1} x_{2}$

\section{RESULTS AND DISCUSSION}

Table 1 shows color, weight loss (\%), shrinkage $(\%)$ and shear force $(\mathrm{N})$ values found in the experimental design. The responses were analyzed to obtain the linear regression equations, the effects and their interactions (Table 2).

The shrinkage results (\%) of the samples ranged from $4.03 \%$ to $9.33 \%$ for formulations 8 and 3 respectively. The formulation with the least shrinkage is the one with the highest levels of added ingredients (F8), while formulation 3 contained the maximum level of collagen and the minimum level of taro flour and whey, which leads us to consider the influence of taro flour and whey in the smallest shrinkage results. This can be confirmed by verifying the significant influence $(p<0.05)$ of the linear effects of taro flour and whey addition (Figure 1a). Both had a negative influence on shrinkage and the greater effect related to whey. The fibers and proteins of taro flour and whey have water retention properties in the product, which contributes to less shrinkage and weight loss.

The values of weight loss after cooking vary from $6.87 \%$ to $22.18 \%$ (F8 and F1), verifying the influence of the higher levels of added ingredients. The isolated factors had a significant influence on the decrease in weight loss, where the greatest influence was whey (\%). According to the response surface (Figure 1b), lower levels of taro flour and whey represent higher values of weight loss. The 
Table 1 - Complete design $2^{3}$ to fishburgers formulations and the obtained responses.

\begin{tabular}{lcccccccccc}
\hline & & & & & & & & & & \\
\hline
\end{tabular}

$x_{1}$ : Taro flour $(\%), x_{2}$ Chicken feet gelatin $(\%), x_{3}$ : Whey $(\%)$.

interaction between the factors of taro flour and whey was significant $(\mathrm{p}<0.05)$ causing an increase in weight loss according to the effects found and this can be explained by the interactions of different macromolecules during cooking.

According to MANAF et al. (2018) when cooking, meat proteins in muscle tend to change in shape and conformation causing lost ability to bind water and the addition of non-meat proteins and fibers can reduce shrinkage and weight loss. COSTA et al. (2019) in a study using industrial byproduct (mechanically separated meat) in fishburgers, shrinkage of $8.0 \%$ to $11.0 \%$ and weight loss of $17.3 \%$ to $35.4 \%$ were found. The presence of whey protein and the pectin-alginate complex in hamburgers, according to BARYBINA et al. (2019), resulted in improved softness, inhibition of lipid oxidation and preservation of product quality, however, greater weight loss $(30.2 \%$ to $37.5 \%)$ was observed than in this study.
Previously, PAULO et al. (2015) compared the shrinkage (\%) and weight loss (\%) of tambatinga and beef burgers and identified an average shrinkage of $6.04 \%$ and weight loss of $18.05 \%$ for that of tambatinga, close to those found in this study, while for the beef burger there was about $15.84 \%$ shrinkage and $37.49 \%$ cooking loss, a greater reduction in size and weight loss than those observed for the tilapia fillet hamburger.

The shear force values ranged from 1.40 $\mathrm{N}$ to $3.09 \mathrm{~N}$ for formulation 5 and 8 respectively. Similar values $(4.0 \mathrm{~N})$ were found in tilapia fishburger (BAINY et al., 2015) and (1.8 $\mathrm{N}$ to 2.9 $\mathrm{N})$ in fishburgers made with washed mechanically separated meat (MSM) from Nile tilapia (COSTA et al., 2019). The formulations that represent the central planning point (F9, F10, F11) presented the firmness values closest to the control $(2.29 \mathrm{~N})$.

Analysis of variance for shear force showed a significant linear effects of collagen from chicken

Table 2 - Mathematic equations and regression coefficients of applied responses to the response surface methodology.

\begin{tabular}{lcc}
\hline Parameters & Equation & $\mathrm{R}^{2}$ \\
\hline Shrinkage & $Y=6.39-0.74 x_{1}-1.11 x_{3}$ & 0.931 \\
Wheight loss & $Y=11.67-2.70 x_{1}-3.73 x_{3}+1.74 x_{1} x_{3}$ & 0.774 \\
Shear force & $Y=2.25+0.36 x_{2}+0.33 x_{1} x_{3}$ & 0.811 \\
$\mathrm{~b}^{*}$ & $Y=14.29-0.24 x_{1}-0.22 x_{1} x_{2}+0.35 x_{1} x_{3}$ & 0.773 \\
\hline
\end{tabular}

$x_{1}$ : Taro flour (\%), $x_{2:}$ Chicken feet gelatin (\%), $x_{3}$ : Whey $(\%), \mathrm{R}^{2}$ : regression factor, $\mathrm{b}^{*}$ : color parameter (yellow/blue intensity). 


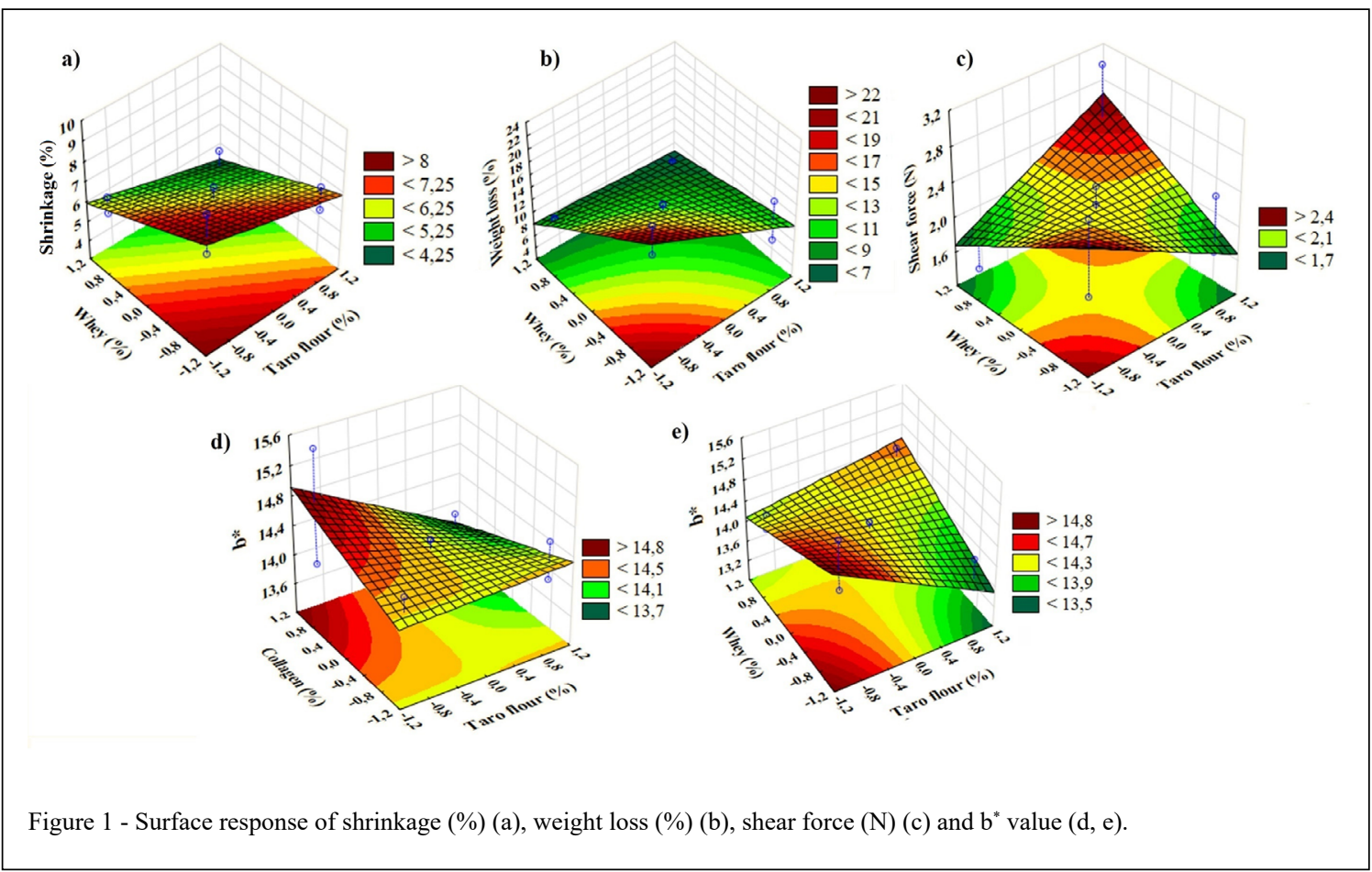

feet $(P$-value $=0.016)$ and for the interaction between taro flour and whey $(P$-value $=0.018)$. There was no evidence of a significant influence of collagen on the softness of formulations. According to FOGAÇA et al. (2013), it is desirable that the product has a soft texture with a low shear force. Using micrographs, they observed that the presence of fat globules and a starch network surrounded by the protein matrix promoted a soft texture. The greatest results for the shear force (Figure 1) were obtained when the values of the extremities of the variables taro flour and whey were used $(-1$ and $-1 ;+1$ and +1$)$.

Lightness $\left(\mathrm{L}^{*}\right)$, and redness $\left(\mathrm{a}^{*}\right)$ values were not affected $(p>0.05)$ by the levels of factors. With values ranging from 64.85 to $73.13\left(\mathrm{~L}^{*}\right)$, hamburgers were lighter than those produced by ALI et al. (2019) with the addition of pumpkin puree or mashed potato (44.16 and 45.07) and COSTA et al. (2019) with mechanically separated meats of nile tilapia (58.10 to $63.40)$. For the chromaticity coordinate $\mathrm{a}^{*}$, the values ranging from -0.46 to 0.47 , that is, a greater tendency to greenish color. Low values of $\mathrm{a}^{*}$ in fishburger are common because they are made from white meat, however they were lower than those reported by ALI et al. (2019) and BAINY et al. (2015).

The regression analysis was significant $(p<0.05)$ for the $b^{*}$ coordinate with values ranging from 13.52 to 15.45 , representing a tendency to yellowish hue, similar to that found by ALI et al. (2019) with about 19.71 to 13.97 . The linear effect of the levels of addition of taro flour and its interaction with collagen exerted negative influence on the $b^{*}$ value. The control formulation had a lower $b^{*}$ value (13.90), which reinforces the influence of factors. According to Figure 1d, high levels of collagen and lower levels of taro flour increase the value of $b^{*}$, while lower levels of whey and higher levels of taro flour decrease the value of $b^{*}$ (Figure 1e).

The proximate composition results are shown in table 3. Similar moisture values were found by TONET et al. (2019), in Nile tilapia hamburgers with manioc flour and MELO et al. (2014) for Tilapia CMS hamburger, with variation in relation to proteins, ashes and lipids. COSTA et al. (2019), in the production of fishburgers published similar results with this research for lipids and high protein content.

The protein content of the formulations had an increase $(p<0.05)$ when compared to the control, mainly in the formulations with higher additions of whey protein and collagen (F8, F7, F5). Significant differences in protein content are observed between formulations due to differences in formulation. There was no difference in the fat content of the samples, 
Table 3 - Proximal composition of tilapia fillet hamburgers formulations.

\begin{tabular}{|c|c|c|c|c|}
\hline \multirow[t]{2}{*}{ Formulations } & \multicolumn{4}{|c|}{ 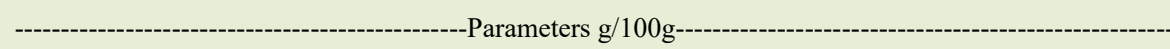 } \\
\hline & Humidity (\%) & Protein (\%) & Lipids (\%) & Ash (\%) \\
\hline Control & $77.05^{\mathrm{a}} \pm 0.37$ & $16.59^{f} \pm 0.28$ & $4.13 \pm 0.08$ & $0,45^{\mathrm{c}} \pm 0,05$ \\
\hline $\mathrm{F} 1$ & $75.27^{\mathrm{ac}} \pm 0.48$ & $18.41^{\mathrm{e}} \pm 0.51$ & $4.19 \pm 0.29$ & $0,65^{\mathrm{b}} \pm 0,06$ \\
\hline $\mathrm{F} 2$ & $73.75^{\mathrm{ad}} \pm 0.44$ & $18.69^{\mathrm{de}} \pm 0.41$ & $4.23 \pm 0.06$ & $0,67^{b} \pm 0,01$ \\
\hline F3 & $74.19^{\mathrm{ae}} \pm 0.44$ & $19.83^{\mathrm{bc}} \pm 0.09$ & $4.30 \pm 0.21$ & $0,66^{b} \pm 0,02$ \\
\hline $\mathrm{F} 4$ & $73.45^{\mathrm{bc}} \pm 0.32$ & $19.35^{\mathrm{cd}} \pm 0.49$ & $4.78 \pm 0.25$ & $0,74^{\mathrm{ab}} \pm 0,05$ \\
\hline F5 & $73.05^{\mathrm{bc}} \pm 0.45$ & $20.60^{\mathrm{ab}} \pm 0.18$ & $4.83 \pm 0.40$ & $0,69^{\mathrm{b}} \pm 0,08$ \\
\hline F6 & $71.47^{b}+0.52$ & $19.53^{\text {cd }}+0.31$ & $4.97+0.03$ & $0,72^{\mathrm{ab}}+0,02$ \\
\hline F7 & $70.36^{\text {bd }} \pm 0.75$ & $21.52^{\mathrm{a}} \pm 0.08$ & $4.86 \pm 0.11$ & $0,74^{\mathrm{ab}} \pm 0,01$ \\
\hline F8 & $69.91^{\mathrm{b}} \pm 0.88$ & $21.11^{\mathrm{a}} \pm 0.03$ & $4.56 \pm 0.34$ & $0,82^{a} \pm 0,03$ \\
\hline F9 & $71.85^{\text {bce }} \pm 0.44$ & $19.69^{\mathrm{bc}} \pm 0.06$ & $4.68 \pm 0.40$ & $0,69^{\mathrm{b}} \pm 0,03$ \\
\hline F10 & $73.02^{\text {bce }} \pm 0.49$ & $19.56^{b c} \pm 0.11$ & $4.78 \pm 0.14$ & $0,67^{\mathrm{b}} \pm 0,07$ \\
\hline F11 & $72.80^{\text {bce }}+0.29$ & $19.93^{b c}+0.53$ & $4.64 \pm 0.27$ & $0,68^{\mathrm{b}}+0,01$ \\
\hline
\end{tabular}

Different letters in the same column indicate statistically significant differences $(\mathrm{P}<0.05)$ in the Tukey'stest.

while the ash content increased in all formulations $(\mathrm{p}<0.05)$ in relation to control. The ash values were low, ranging from $0.65 \%$ to $0.82 \%$ for $\mathrm{F} 1$ and $\mathrm{F} 8$ respectively, which represent the lowest and highest levels of factors in the planning. Low ash contents $(0.67 \%$ to $1.09 \%)$ were also reported by MAIA et al. (2015) in Nile tilapia hamburgers. Taro flour has considerable amounts of ash (1.64\% to $3.11 \%)$ (ARICI et al., 2016), as well as chicken feet collagen (1.91\%) (ALMEIDA \& LANNES, 2013) and probably influenced the differences between formulations.

In the samples was found $9.2 \mathrm{NMP} / \mathrm{g}$ of total coliforms, $<3.0 \mathrm{NMP} / \mathrm{g}$ of fecal coliforms, $<10^{3}$
CFU/g for coagulase-positive Staphylococcus and absence of Salmonella spp. in $25 \mathrm{~g}$, which complies with the legislation (BRAZIL, 2001).

Color, aroma, taste, texture and overall acceptability of formulated fishburgers were not affected $(p>0.05)$ by the levels of addition of taro flour, collagen and whey (Table 4). The differences in color and shear force found in instrumental analyzes were not noticeable by the tasters. The means of sensorial acceptability in all attributes were between "like moderately" and "like very much" on the hedonic scale, values higher than those prepared with Nile tilapia CMS (COSTA et al., 2019) and similar to

Table 4 - Sensory evaluation and intention to purchase of tilapia hamburgers.

\begin{tabular}{|c|c|c|c|c|}
\hline \multirow[t]{2}{*}{ Sensory attributes } & \multicolumn{4}{|c|}{ 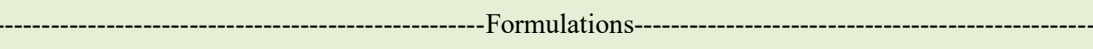 } \\
\hline & Control & $\mathrm{F} 1$ & F8 & F9 \\
\hline Color & $7.39 \pm 1.20$ & $7.55 \pm 1.32$ & $7.45 \pm 1.39$ & $7.48 \pm 1.30$ \\
\hline Aroma & $7.53 \pm 1.35$ & $7.42 \pm 1.36$ & $7.42 \pm 1.37$ & $7.43 \pm 1.42$ \\
\hline Texture & $7.86 \pm 1.17$ & $7.63 \pm 1.26$ & $7.60 \pm 1.39$ & $7.63 \pm 1.19$ \\
\hline Taste & $7.65 \pm 1.58$ & $7.95 \pm 1.28$ & $7.82 \pm 1.32$ & $7.75 \pm 1.32$ \\
\hline Overall Impression & $7.76 \pm 1.22$ & $7.94 \pm 1.05$ & $7.85 \pm 1.10$ & $7.85 \pm 1.03$ \\
\hline \multicolumn{5}{|c|}{ 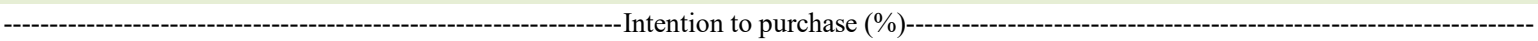 } \\
\hline 1. Centainly not buy & 2.56 & 1.28 & 2.56 & 1.28 \\
\hline 2. Possibly not buy & 5.13 & 6.41 & 8.97 & 1.28 \\
\hline 3. Maybe buy/ Maybe not buy & 23.08 & 21.79 & 12.82 & 21.79 \\
\hline 4. Possibly buy & 26.92 & 24.36 & 35.90 & 35.90 \\
\hline 5. Certainly buy & 42.31 & 46.15 & 39.74 & 39.74 \\
\hline
\end{tabular}

Ciência Rural, v.51, n.2, 2021. 
those observed by SILVA et al. (2016) and MAIA et al. (2015) in fishburgers.

Approximately $46.2 \%$ of the tasters would certainly buy (Table 4 ) the test $\mathrm{F} 1$ represented by the addition of the lowest levels of the studied variables, while F8 and F9 were the same (39.7\%). These values are of purchase conviction, however, if we consider the classifications that indicate positive probability of purchase such as: I have doubts if I would buy, I would probably buy and I certainly would buy, all formulations had a competitive possibility. Control, F1, F8 and F9, about $92.3 \%, 92.3 \%, 88.5 \%$ and $97.4 \%$ of the tasters could buy, respectively. Thus, the formulation with the highest purchase intention was the one that contains the intermediate quantities of the tested ingredients (F9), represented by the central point of factorial design.

\section{CONCLUSION}

Fishburgers made with taro flour, chicken feet collagen and whey showed high protein levels and ash content than the control formulation demonstrating the potential of using industry byproducts to add nutritional value to fish products. The factorial design demonstrated that for the shrinkage $(\%)$ and weight loss (\%) responses, the parameters taro flour and whey had significant negative effects $(p<0.05)$ and contributed to a higher yield of fishburgers, being a factor important technological.

The greater addition of the studied parameters caused a greater shear force due to the significant action of collagen and the interaction between taro flour and whey, although all formulations were soft. The results of the expressive sensory acceptance for all formulations and high purchase intention indicate that the addition of taro flour $(3.0 \%)$, chicken feet collagen $(0.5 \%)$ and whey $(3.0 \%)$, represented by F9 was the most suitable.

\section{DECLARATION OF CONFLICT OF INTERESTS}

The authors declare no conflict of interest. The founding sponsors had no role in the design of the study; in the collection, analyses, or interpretation of data; in the writing of the manuscript, and in the decision to publish the results.

\section{BIOETHICS AND BIOSSECURITY COMMITTEE APPROVAL}

The Research Ethics Committee (CEP) of the Federal Institute of Mato Grosso approved this study under opinion number 2.693.200, June 5, 2018

\section{ACKNOWLEDGEMENTS}

The authors are grateful to the Federal Institute of Mato Grosso and Research Support Foundation of Mato Grosso State (FAPEMAT) for providing financial support for this research.

\section{AUTHORS' CONTRIBUTIONS}

Poliana Fernandes de Almeida and Christiane Neves Maciel conceived and designed experiments. Christiane Neves Maciel, Luiz Fernando Florêncio Seller and Agnaldo Borge de Souza performed the experiments and laboratory analyzes. Poliana Fernandes de Almeida supervised, coordinated the experiments and performed statistical analysis of experimental data. Christiane Neves Maciel and Poliana Fernandes de Almeida prepared the draft of the manuscript. All authors critically reviewed the manuscript and approved the final version.

\section{REFERENCES}

ABERA. G. et al. Effect of drying methods and blending ratios on dough rheological properties.physical and sensory properties of wheat-taro flour composite bread. Food Science Nutrition, v.5, p.653-661, 2017. Available from: <https://www.ncbi.nlm.nih.gov/ pmc/articles/PMC5448375/pdf/FSN3-5-653.pdf>. Accessed: Apr. 22, 2020. doi: $10.1002 /$ fsn 3.444 .

BARYBINA, L. I. et al. Hamburger patty development with alginate-pectin meat emulsion. Journal of Hygienic Engineering and Design, v.29, 2019, p.111-118.

ALI, H. A. et al. Evaluation of tilapia fishburgers as affected by different replacement levels of mashed pumpkin or mashed potato. Journal of the Saudi Society of Agricultural Sciences, v.18, p.127-132, 2019. Available from: <https://www.sciencedirect. com/science/article/pii/S1658077X16302004?via\%3Dihub>. Accessed: Apr. 22, 2020. doi: 10.1016/j.jssas.2017.01.003.

ALMEIDA, P. F.; LANNES, S. C. S. Extraction and physicochemical chatacterization of gelatin from chicken byproduct. Journal of Food Process Engineering, v.36, p.824833. 2013. Available from: <https://onlinelibrary.wiley.com/doi/ abs/10.1111/jfpe.12051>. Accessed: Apr. 22, 2020. doi: 10.1111/ jfpe. 12051 .

ALMEIDA, P. F.; LANNES.S. C. S. Effects of chicken by-product gelatin on the physicochemical properties and texture of chocolate spread. Journal of Texture Studies, p.1-11, 2017. Available from: $<$ https://onlinelibrary.wiley.com/doi/abs/10.1111/jtxs.12242>. Accessed: Apr. 22, 2020. doi: 10.1111/jtxs.12242.

BRAZIL, Ministry of Health. Health Surveillance Secretariat. RDC Resolution $\mathrm{N}^{\mathrm{o}} 12$ of January 2, 2001. Technical regulation on microbiological standards in food. Available from: $<$ https://www. defesa.agricultura.sp.gov.br/legislacoes/instrucao-normativa-sda62-de-26-08-2003,665.html>. Accessed: Nov. 23, 2019.

AOAC. Official methods of analysis of the AOAC. Viriginia: International Association of Official Analytical Chemists, 2000.

ARICI. M. et al. Physicochemical and nutritional properties of taro flour as affected by drying temperature and air velocity. LWT - Food Science and Technology, v.74, p.434-440, 2016. Available from: <https://www.sciencedirect.com/science/article/pii/ 
S0023643816304923>. Accessed: Apr. 22, 2020. doi: 10.1016/j. lwt.2016.08.006.

BAINY, E. M et al. Physical changes of tilapia fishburger during frozen storage. B.CEPPA, v.33, n.2, 2015. Available from: $<$ https://revistas.ufpr.br/alimentos/article/view/47171>. Accessed: Apr. 22, 2020. doi: 10.5380/cep.v33i2.47171.

COSTA, D. P. S. et al. Potentiality of using mechanically separated meats of nile tilapia in fishburgers: Chemical, physical and sensory characterization. Brazilian Archives of Biology and Technology, v.62, e.19180436, p.1-12, 2019. Available from: <http://www. scielo.br/pdf/babt/v62/1516-8913-babt-62-e19180436.pdf $>$. Accessed: Apr. 22, 2020. doi: 10.1590/1678-4324-2019180436.

DIAS. J. S. R. et al. Obtaining yam flourfor the preparation of cereal bar as a food and functional supplement. Brazilian Journal of Development. v.6, n.3, p.15716-15735, 2020. Available from: $<$ http://www.brjd.com.br/index.php/BRJD/article/view/8196/7066>. Accessed: Apr. 22, 2020. doi: 10.34117/bjdv6n3-446.

FELlOWS, P. J. Tecnologia do Processamento de Alimentos: Porto Alegre: Artmed, 2006. p.481-482.

FOGAÇA, F. H. S.et al. Optimization of the surimi production from mechanically recovered fish meat (mrfm) using response surface methodology. Journal of Food Quality, v.36, p.209-216, 2013. Available from: <https://ainfo.cnptia.embrapa.br/digital/ bitstream/item/86230/1/JournalFoodQualityFabiolaFogaca.pdf $>$. Accessed: Apr. 22, 2020. doi: 10.1111/jfq.12019.

FUNAMI, T. Next target for food hydrocolloid studies: texture design of foods using hydrocolloid technology. Food Hydrocolloids, v.25, p.1904-1914, 2011. Available from: <https://www.sciencedirect. com/science/article/pii/S0268005X11000889>. Accessed: Apr. 22, 2020. doi: 10.1016/j.foodhyd.2011.03.010.

OLIVEIRA, R. B. S. et al. Quality of beef burger with addition of wet okara along the storage. Ciência e Agrotecnologia, v.40, n.6, p.706-717, 2016. Available from: <http:/www.scielo.br/ scielo.php?script $=$ sci arttext\&pid $=\mathrm{S} 1413-70542016000600706>$. Accessed: Apr. 22, 2020. doi: 10.1590/1413-70542016406005816.

MAIA, M. O. et al.Natural thickener in raw and cooked fish-derived: microbiological, physicochemical and sensorial acceptance. Científica, v.43, n.3, p.215-220, 2015. Available from: <http://cientifica.org.br/ index.php/cientifica/article/view/673/421>. Accessed: Apr. 22, 2020. doi: 10.15361/1984-5529.2015v43n3p215-220.

MANAF, F. A. et al. Physicochemical properties and consumer Preference of Fishburgers Produced from Black Tilapia Surimi Paste and Potato Flour. MJoSHT, v.1, n.1, p.25-30, 2018. Available from: <http://mjosht.usim.edu.my/index.php/mjosht/ article/view/11/6>. Accessed: Apr. 22, 2020. ISSN 2601-0003.

MELO H. M. G. et al. The fishburger quality of mechanically recovered meat from tilapia using added wheat fibre and corn oil. ARS Veterinária, v.30, n.1, p.023-031.2014. Available from: $<$ http://arsveterinaria.org.br/index.php/ars/article/view/562>. Accessed: Apr. 22, 2020. doi: 10.15361/2175-0106.2014v30n $1 \mathrm{p} 23-31$.

NJINTANG. N. Y.et al. Other Taro-based Products. In: SHARMA. H. K.; NJINTANG. N. Y.; SINGHAL. R.; S.; KAUSHAL. P. Tropical Roots and Tubers: Production, process and technology. Wiley-Blackwell, 2016. Cap.9.3, p.395-413.
OMAR. S. et al. Design and validation of short-Amplicon Length PCR Assay for the Detection of Porcine Gelatin in Commercial Candy and Marshmallow Products. Current Research in Nutrition and Food Science. v.6, n.3, p.742-747. 2018. Available from: $<$ https://www.foodandnutritionjournal.org/volume6number3/ design-and-validation-of-short-amplicon-length-pcr-assay-forthe-detection-of-porcine-gelatin-in-commercial-candy-andmarshmallow-products/>. Accessed: Apr. 22, 2020. doi: 10.12944/ CRNFSJ.6.3.16

PAULO. I. G. P. et al. Assessment of contents loss of fishburguer prepared with the tambatinga filet (Colossoma macropomum $x$ Piaractus brachpomus). Revista Brasileira de Engenharia de Pesca, ed. 8, n.2.p. 26-33. 2015. Available from: <https://ppg.revistas.uema.br/index.php/REPESCA/ article/view/1099>. Accessed: Apr. 22, 2020. doi: 10.18817/ repesca.v8i2.1099.

KILARA. A.; VAGHELA.M.N. Whey proteins. In: YADA. R. Y. Proteins in food processing. United Kingdom: Woodhead Publishing, 2018. Cap.4, p.93-126.

RIOS, R. V. et al. Application of fats in some food products. Food Science and Technology, v.34, n.1, p.3-15, 2014. Available from: <https://www.semanticscholar.org/paper/ Application-of-fats-in-some-food-products-Rios-Pessanha/ dd58f25434b89dde720646468fe75eb7cf83c65a>. Accessed: Apr. 22, 2020. doi: 10.1590/S0101-20612014000100001.

SANTANA. J. C. C. et al. Valorization of chicken feet byproduct of the poultry industry: high qualities of gelatin and biofilm from extraction of collagen. Polymers. v.12. n.529. p.1-21. 2020. Available from: <https://www.mdpi.com/20734360/12/3/529>. Accessed: Apr. 22, 2020. doi: 10.3390/ polym 12030529 .

SARBON. N. M. et al. Preparation and characterisation of chicken skin gelatin as an alternative to mammalian gelatin. Food Hydrocolloids, v.30. p.143-151. 2013. Available from: $\quad<$ https://www.sciencedirect.com/science/article/pii/ S0268005X12001099>. Accessed: Apr. 22, 2020. doi: 10.1016/j. foodhyd.2012.05.009.

SILVA. M. A. P. et al. Elaboration of saramunete (Pseudupeneus maculatos) fishburger using different types of vegetable. Revista Brasileira de Engenharia de Pesca, v.9, n.2, p.36-51, 2016. Available from: <http://ppg.revistas.uema.br/index.php/ REPESCA/article/view/1043>. Accessed: Apr. 22, 2020. doi: 10.18817/repesca.v9i2.1043.

STONE. H.; SIDEL. J. L. Sensory evaluation practices. 2.ed. San Diego: Academis Press.1993, 338p.

TONET, A. et al. Biological activity and quantification of bioative compounds in yerba mate extract and its application in fish hamburger. Brazilian Journal Food Technology, v.22, e2018054, p.1-12, 2019. Available from: <http://www.scielo.br/pdf/bjft/ v22/1981-6723-bjft-22-e2018054.pdf>. Accessed: Apr. 22, 2020. doi: 10.1590/1981-6723.05418.

TREVISAN. Y. C.et al. Effect of the addition of oat fiber on the physicochemical properties of cooked frozen hamburger with reduced fat and salt. Brazilian Journal of Food Technology, v.19, 2016. Available from: <https://www.scielo.br/pdf/bjft/v19/19816723-bjft-1981-67237915.pdf $>$. Accessed: Apr. 22, 2020. doi: 10.1590/1981-6723.7915. 